\title{
胆道癌再発に対する外科的治療
}

\begin{tabular}{|c|c|c|c|c|c|c|c|}
\hline \multicolumn{8}{|c|}{ 名古屋大学医学部第 1 外科 } \\
\hline 近藤 & 哲 & 二村 & 雄次 & 早川 & 直和 & 神谷 & 順一 \\
\hline 久保田 & 化 & 前田 & 正司 & 河野 & 弘 & 早川 & 英男 \\
\hline 椰野 & 正人 & 井垣 & 啓 & 小> & 清二 & 金井 & 道夫 \\
\hline 首家 & 充 & 高木 & 敏貴 & 加藤 & 政隆 & 塩里 & 恵彦 \\
\hline
\end{tabular}

\section{SURGICAL TREATMENT FOR RECURRENCE OF BILIARY TRACT CANCER}

\author{
Satoshi KONDO, Yuji NIMURA, Naokazu HAYAKAWA, \\ Junichi KAMIYA, Hitoshi KUBOTA, Shoji MAEDA, \\ Hiroshi KONO, Hideo HAYAKAWA, Masato NAGINO, \\ Hiroshi IGAKI, Seiji OGISO, Michio KANAI, \\ Mitsuru DOKE, Toshitaka TAKAGI, Masataka KATO \\ and Shigehiko SHIONOYA
}

First Department of Surgery, Nagoya University School of Medicine

過去 8 年 8 か月間に相対非治瘦切除以上の治痘度をもって切除しえた胆道癌症例のらち再発が確認 されたのは42例で, $5 ち 9$ 例に再発巣切除を，5例に外科的動注療法 ( 3 例は両者併用)を施行した。 再発巣切除により 6 か月〜 3 年 3 か月, 平均 1 年 7 か月経過した 4 例の非担癌生存例が得られた。癌 死した 4 例でも平均生存期間は 1 年 4 か月で延命効果や quality of life の改善が得られたものと考克 ている，この経験から，再発巣がその葴器内で限局性であれば葴器欠損に対する再建方法を考睬した 上で，積極的に切除にのぞむべきと考えられた。特に手術創ないしは外胆汁瘦孔への癌細胞播種によ ると考えられる胸腹壁再発例では，視触診で早期に発見し状況が許せば開腹術も付加して十分に切除 すべきである。

蔂引用語：胆道癌再発切除，乳頭部癌再発切除，手術創部癌再発，外胆汁㾞孔部癌再発

はじめに

画像診断の進歩や手術術式の改善に伴い胆道癌の治 療成績は向上しつつあるものの, いまだ満足のいくも のではない1)。童してや再発例の治療成績に関しては まとまった報告もほとんどなく，外科的治㞠のおよぶ 余地もないというのが現状のようである。われわれは 拡大手術もまじえて積極的に胆道癌を切除してきてい るが223), 再発例に対しても積極的に外科的治療を施行 しているのでその成績を報告し，今後の治療方針につ いて述べる.

$<1988$ 年 7 月 13 日受理 $>$ 別刷請求先 : 近藤 哲 T466 名古屋市昭和区鶴舞町65 名古屋大学医学部 第 1 外科

\section{対象}

1979年 1 月から1987年 8 月までの 8 年 8 か月間に教 室で経験した胆道癌は他葴器重複癌 6 例を除くと 140

表 1 胆道癌症例

'79. 1-'87. 8 名大 1 外 他臟器重複癌 6 例を除く

\begin{tabular}{|c|c|c|c|c|}
\hline & 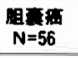 & $\begin{array}{l}\text { 䏣管虚 } \\
\mathrm{N}=73\end{array}$ & 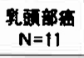 & $\underset{N=140}{\substack{c t \\
N}}$ \\
\hline 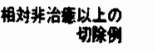 & $41(3)$ & $57(5)$ & $9(1)$ & 107 (9) \\
\hline 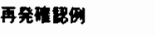 & 22 & 18 & 2 & 42 \\
\hline 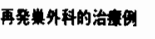 & 7 & 3 & 1 & 11 \\
\hline $\int$ & $6(1)$ & $2[1]$ & 1 [1] & 9 (3) \\
\hline lu注のk & 1 & 1 & & 2 \\
\hline
\end{tabular}


例である(表 1)，癌の遺残が明らかでない，すなわち 相対非治癒切除4 以上の治癒度をもって切除しえたの は107例で, 手術死亡 9 例を除いた 98 例中 42 例 $43 \%$ に再 発が確認されている。疾患別に再発率をみると胆襄癌 $58 \%$ ，胆管癌 $35 \%$ ，乳頭部癌 $25 \%$ あった。

教室では再発例に対しても病巣が限局していて切除 再建が可能であれば積極的に切除を行い，切除不能の 場合には外科的動注療法(以下動注)，すなわち通院可
能例には間歇動注リザーバー植込みを，入院例には持 続動注カテーテル插入をいずれも非開腹下に行うこと を基本方針としている。これらの外科的治療を，再発 確認例の $26 \%$ にあたる11例に施行しており，これを対 象として治療成績を中心に検討した。切除例は 9 例で らち 3 例は動注む併用している。胆雯癌では再発例の $27 \%$ にあたる 6 例が切除されているが，胆管癌では再 発例の $11 \%$ \%あたる 2 例にとどまっている。なお，動

表 2 胆愛癌再発巣切除例

\begin{tabular}{|c|c|c|c|c|c|c|}
\hline 症 例 & 初 & 初発巣切除術式 & 再 発 & 再発栄切除術式 & 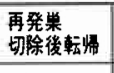 & $\begin{array}{l}\text { 初發菓 } \\
\text { 切除後 }\end{array}$ \\
\hline \multirow[t]{2}{*}{ 1. $\begin{array}{l}55 \\
\text { 女 }\end{array}$} & \multirow[t]{2}{*}{ 詳細不明 } & \multirow[t]{2}{*}{ 䏣 摘 } & $\begin{array}{c}4 \text { 年後 } \\
\text { 腹壁·肝門暗 }\end{array}$ & 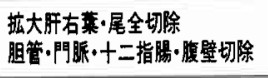 & $\begin{array}{c}\text { 1年4 } 4 \text { 䐺死 } \\
\text { (肺) }\end{array}$ & \multirow{2}{*}{5 年 4か月 } \\
\hline & & & $\begin{array}{c}\text { 8か月後 } \\
\text { 右内湖リンハ蔽 }\end{array}$ & 胸骨維切開リンハ節郭清 & 8か月 & \\
\hline 2. $\begin{array}{l}64 \\
\text { 女 }\end{array}$ & $\begin{array}{l}\text { 全体癌 Stage } \\
\mathrm{S}_{3} \mathrm{~N}_{3} \mathrm{Hinf}_{3} \mathrm{Binf}_{3}\end{array}$ & $\begin{array}{l}\text { 胢右3区域·尾全切除 } \\
\text { PD }\end{array}$ & 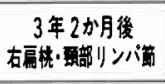 & 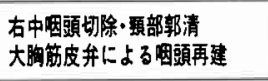 & $\begin{array}{l}\text { 6か月生 } \\
\text { 非担癌 }\end{array}$ & 3年8か月 \\
\hline $\begin{array}{l}77 \\
\text { 女 }\end{array}$ & $\begin{array}{l}\text { 全体需 StageN } \\
\mathrm{S}_{3} \mathrm{~N}_{2} \mathrm{Hinf}_{1} \text { Binf }_{3}\end{array}$ & $\begin{array}{l}\text { 应大所右菜·尾全切除 } \\
\text { PD }\end{array}$ & $\begin{array}{l}8 \text { か月後 } \\
\text { 腹 壁 }\end{array}$ & 腹壁·所部分切除 & $\begin{array}{c}\text { 1年3加路生 } \\
\text { 非担复 }\end{array}$ & 1年11か月 \\
\hline 4. 62 & $\begin{array}{l}\text { CGn StageN } \\
S_{1} N_{1} H_{i n f} B_{2} \operatorname{Binf}_{3}\end{array}$ & $\begin{array}{l}\text { 遮大所右藮·尾全切除 } \\
\text { 阻管切除 }\end{array}$ & $\begin{array}{l}\text { 5か月後 } \\
\text { 腹 壁 }\end{array}$ & 筷等·所部分切除 & 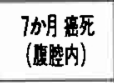 & 1 年 \\
\hline $\begin{array}{l}61 \\
\text { 男 }\end{array}$ & $\begin{array}{l}\text { Gfb StageV } \\
\mathrm{S}_{2} \mathrm{~N}_{2} \mathrm{Hinf}_{3} \text { Binfo }\end{array}$ & 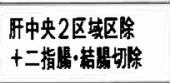 & $\begin{array}{l}4 \text { 只月後 } \\
\text { 腹 腃 }\end{array}$ & 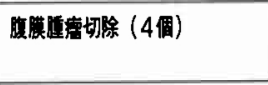 & $\begin{array}{c}\text { 3年3加生 } \\
\text { 非担悪 }\end{array}$ & 3年 7か月 \\
\hline \multirow[t]{2}{*}{$\begin{array}{l}67 \\
\text { 女 }\end{array}$} & \multirow[t]{2}{*}{$\begin{array}{l}\text { Gn Stagell } \\
S_{0} N_{1} \text { Hinfo Binfo }_{0}\end{array}$} & \multirow[t]{2}{*}{$\begin{array}{l}\text { 阻床切除 } \\
\text { 䏣管切除 }\end{array}$} & 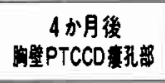 & 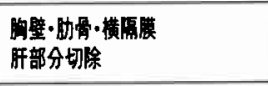 & 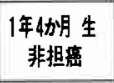 & \multirow{2}{*}{ |年8か月 } \\
\hline & & & $\begin{array}{l}\text { 10か月後 } \\
\text { 间 部 }\end{array}$ & 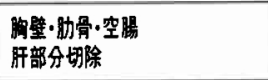 & 6か月 & \\
\hline
\end{tabular}

尾：尾状葉

$\mathrm{PD}$ : 膵頭十二指腸切除

表 3 胆管癌・乳頭部癌再発栄切除例

\begin{tabular}{|c|c|c|c|c|c|c|}
\hline 症 例 & 初 & 初発巣切除術式 & 再 & 再発眘切除術式 & \begin{tabular}{l|} 
再発巣 \\
切除後転帰 \\
\end{tabular} & $\begin{array}{l}\text { 初発単 } \\
\text { 切除後 } \\
\end{array}$ \\
\hline $\begin{array}{l}\text { 7. } 57 \\
\text { 女 }\end{array}$ & $\begin{array}{l}\text { 左肝内 Stage IIl } \\
\text { So } N_{3} H_{\text {Hinf } 1} V_{0}\end{array}$ & $\begin{array}{l}\text { 列左3区域・尾全切除 } \\
\text { 胆管切除 }\end{array}$ & $\begin{array}{c}\text { 2年 4か月後 } \\
\text { 腹壁PTCD侓孔部 }\end{array}$ & 腹壁切除 & $\begin{array}{c}1 \text { か月他病死 } \\
\text { (肝不全) }\end{array}$ & 2年5か月 \\
\hline \multirow[t]{5}{*}{$\begin{array}{l}\text { 8. } 49 \\
\text { 男 }\end{array}$} & \multirow[t]{5}{*}{$\begin{array}{l}\text { Bsir Stage I } \\
\text { So } N_{0} \text { Hinfo } V_{0}\end{array}$} & \multirow{5}{*}{$\begin{array}{l}\text { 肝左葉内側下区域 } \\
\text { 部分·尾全切除， } \\
\text { 䏣管切除 }\end{array}$} & $\begin{array}{r}\text { 6か月後 } \\
\text { 胸壁皮下 }\end{array}$ & 皮下堙瘤切除 & $\begin{array}{c}\text { 1年6か力膆死 } \\
\text { (腹膜・肝) }\end{array}$ & \multirow{5}{*}{2 年 } \\
\hline & & & $\begin{array}{l}\text { 7か月後 } \\
\text { 腹壁皮下 }\end{array}$ & 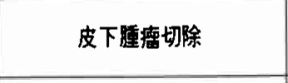 & 11か月 & \\
\hline & & & $\begin{array}{c}\text { 1か月後 } \\
\text { 腹腔内·腹壁 }\end{array}$ & 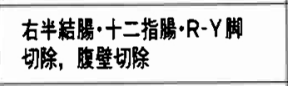 & 10か月 & \\
\hline & & & $\begin{array}{c}2 \text { か月後 } \\
\text { 胸壁皮下 }\end{array}$ & 皮下腄瘦切除 & 8か月 & \\
\hline & & & 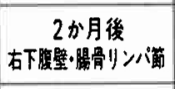 & 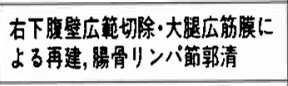 & 6か月 & \\
\hline $\begin{array}{l}\text { 9. } 64 \\
\text { 女 }\end{array}$ & $\begin{array}{l}\text { A Stage II } \\
\text { DoN, Panco }\end{array}$ & PD & $\begin{array}{l}9 \text { か月後 } \\
\text { 肝 }\end{array}$ & $\begin{array}{l}\text { 肝外側区域切除 } \\
\text { 腹壁切除 }\end{array}$ & $\begin{array}{l}\text { |年11か月監死 } \\
\text { (所・リンハ䔮) }\end{array}$ & 2年8か月 \\
\hline
\end{tabular}


注のみ施行したのは 2 例だけであった。

\section{結 果}

再発巣切除例の概要を表に示した（表 2，3）.

症例 1 は他医で胆囊摘出術後 4 年目に腹壁創部に再 発をきたして紹介され(図 1)，精査の結果肝門部にも 径 $3 \mathrm{~cm}$ の腫瘤が発見され(図2), 腹壁切除亡ともに抎 大肝右葉 - 尾状葉・胆管切除, 門脈・十二指腸合併切 除を施行した(図 3). 腹腔内にリンパ節転移はなかっ たが，腹壁再発巣からと考壳られる前下縦隔リンパ節 転移を認めた。さらに8 か後には右内胸リンパ節転 移が明らかとなりこれも郭清したが，肺転移が出現し

図 1 胆囊摘出術後 4 年目に発生した腹壁創部再発巣 (症例 1 )

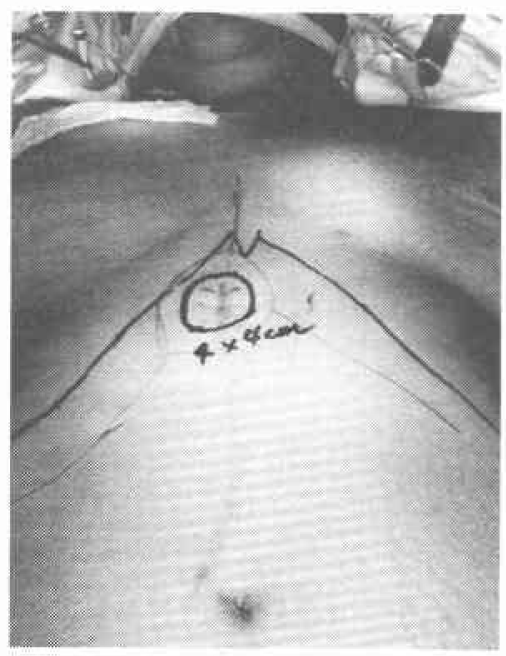

図 2 腹腔内再発巣の所見(症例 1)

左上：右肝動脈, 右後区域枝に encasement を認める. 左下：門脈本幹に狭窄を認める。右：無黄疾であった が，PTCを行う之肝外胆管に压排性狭窄が認められ た.
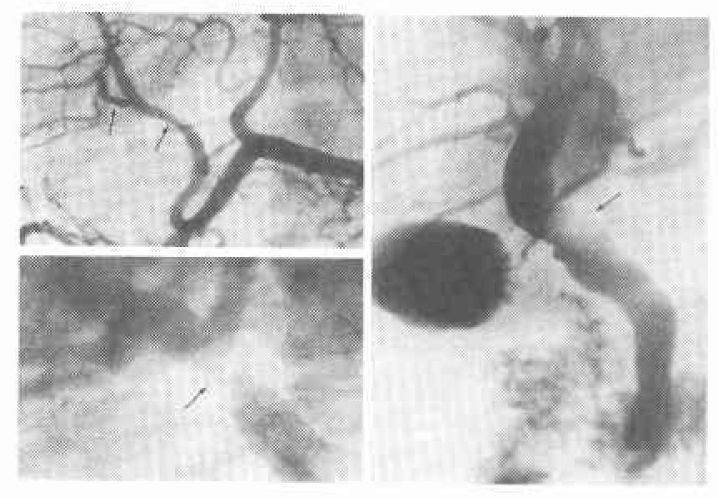

因 3 切除標本（症例 1 )

胆管と門脈を後面切開したところで，ともに浸潤が認 められた。胆篦管断端の再発と考えられる，RHD：右 肝管開口部, $\mathrm{CD}$ ：胆襄管開口部, RPV：門脈右枝開口 部

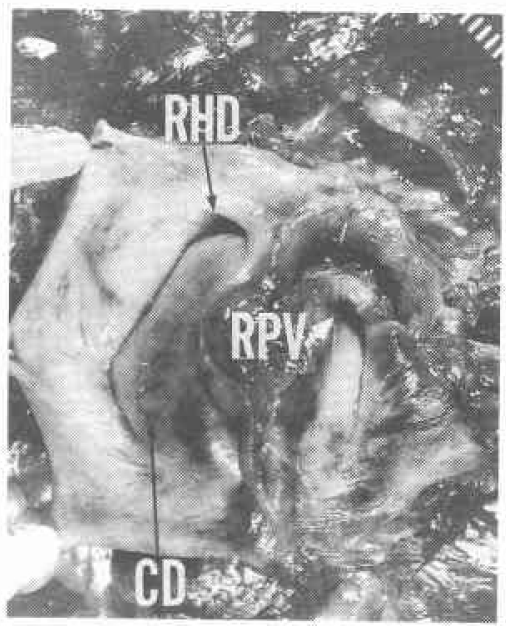

数回の one shot 動注も効果なく初再発巣切除後 1 年 4 か月で癌死した，腹腔内の再々発はなく，腹壁再発 をもっと早期に診断し切除がなされていたらと悔まれ る症例であった。

症例 2 はきわめて高度に進行した塊状型胆囊癌例 で, 肝右 3 区域・尾状葉切除, 膵頭十二指腸切除後 3 年 2 か月で血行性と考学られる右扁桃転移をきたし, 右中咽頭切除・右根治的頸部郭清，大胸筋皮弁による 咽頭再建が施行された。その後 6 か月経過したが, 腹 部・胸部ともに再々発は認められていない。

症例 5 法胆囊粘液癌例5)で, 初回切除の 4 か月後に 疻着性イレゥスで開腹した際, 偶然に大豆大から慆卵 大までの 4 個の腹膜再発が見つかり切除しえた。 その 後 3 年 3 か月経過したが再々発の徵候はない。

症例 8 は Stage I の胆管癌でありながら, 初発巣切 除の 6 か月後から次々と腹壁創部, 腹腔内, 腹壁内之 再発をさたした症例で, 初発巣切除前に他医で胆管切 開腫晹生検を受けた時の implantation が原因之考克 られる. 計 5 回にわたる再発巣切除, 動注併用にもか かわらず初再発巣切除後 1 年 6 か月 $\mathrm{P}_{3} \mathrm{H}_{3}$ の状態で癌 死した。

これら再発巣切除 9 例に打ける1つの特徵は, 初再 発部位が 6 例で胸腹壁であったことである(表 4)。そ の診断法はいずれも視触診によるすのであり，腹膜， 肝再発の 2 例以外は腫瘍マーカーも正常範囲内であっ 
表 4 切除例の初再発部位と䛦断法

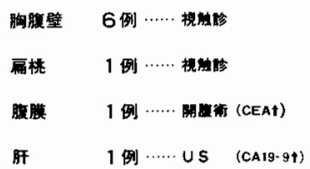

図 4 胆道癌再発巣切除例の転㷌

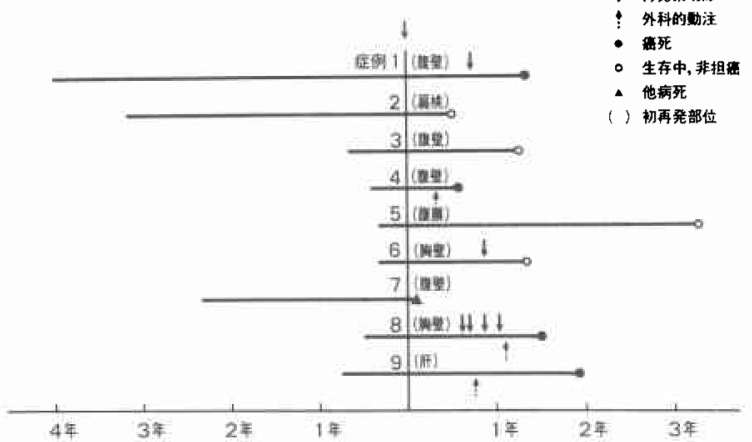

た.

再発巣切除例の転㷌は非担癌生存中 4 例, 癌死 4 例, 他病死 1 例であった(図 4). 初発巣の進行度, 初再発 までの期間, 初再発部位などと予後との間に一定の関 係は見いだせなかった。

癌死した 4 例の平均生存期間は初再発巣切除から1 年 4 か月, 初発巣切除から 2 年 9 か月であり, 生存中 の 4 例の平均経過期間は初再発巣切除加 1 年 7 力 月, 初発巣切除から 2 年 9 か月であった。動注は症例 9 にのみ 1 年 2 か月の生存期間が党られたが, 動注の みの 2 例も含めた他の 4 例では 7 か以内に癌死して おり，5例全例の平均生存期間は動注開始後 6 か月で あった。

\section{考察}

胆道癌再発例に対しては，一般的には化学療法・放 射線療法牧などが主たる治療法となっているが，有効 なものとはいいがたい. 切除を主とした外科的治療法 の報告はきわめて少なく, 再発巣切除により長期生存 が得られた症例報告7)8)が散見されるにすぎない.

自験例では 9 例に再発巣切除を行い, 初再発巣切除 から 6 か月〜 3 年 3 か月，平均 1 年 7 か月経過した 4 例の非担癌生存例が得られている.このうちの 2 例(症 例 3，5）はさらに長期生存を期待しらるものと考光 られる。 また癌死した 4 例でも初再発巣切除から 7 か 月一 1 年11か月, 平均 1 年 4 か月の生存期間が得られ ており，延命効果や quality of life の改善が得られた
ものと考穴ている。一方，動注例では平均生存期間 6 か月と予後不良であった。しかしながら再発巣が限局 性である場合には切除を行い，すでに切除不能となっ た時点で動注を開始しているため，この結果が即動注 は無効であることを意味するものではない. 動注症例 数が少ないこともありさらに検討が必要である。

再発巣切除の成績が比較的良好であったのは，当然 のことながら再発巣が限局している症例に適応を限っ たことによると考劣られる。再発巣を可及的早期に発 見すべきことはいらまでもないが，発見されたとさに は腹腔内を中心に全身にわたり他の再発单の検索を詳 細に行らべきである。症例 1 は腹壁再発で来院したが， 各種画像診断により径 $3 \mathrm{~cm}$ の肝門部再発を無黄㾝の らちに診断でさ，適切な切除を行らことができた。残 念ながら腹壁再発に由来する再々発により失ったが， 腹腔内再々発は画像診断上最後交で認めなかった。

再発巣が限局した症例に切除の適応をしばっている ため，初再発部位は 9 例中 6 例が胸腹壁であり腹膜， 肝再発は少なかった，胸腹壁再発は術中の implantationによると考えられるるのが 4 例, 経皮経肝胆管ド レナージ (PTCD), 経皮経肝胆囊ドレナージ (PTCCD) 瘦孔への implantation \& 2 例に認められ ている. implantation による再発は限局している可能 性があり，可及的早期に診断し切除すべきであるが， 胸腹壁再発には画像診断や腫瘍マーカーは無力であ り，丹念に視触診を繰り返すことが重要である. 切除 に際しては他の再発巣を見落とさないようにすること が肝要で， 6 例中 3 例が同時性にまたは後に腹腔内に も再発をきたしていることを考慮すると, 状況が許せ ば開腹術も付加して腹腔内再発を検索するとともに, 十分な余裕をもって腹壁再発を切除することが肝要と 考学られる。

再発巣切除にあたり注意すべき事は, 非定型的, 変 則的な切除となる場合が多いため, 缄器欠損に対する 再建方法を個々の症例に応じて考慮すべきことであ る。自験例では, 症例 2 の咽頭再建, 症例 8 の腹壁再 建などに形成外科, 耳鼻咽喉科など他科の協力を得て 積極的にのぞんでいる.

\section{まとめ}

1. 胆道癌再発例でも再発巣切除により, 延命効果, quality of life の改善が得られ, さらに長期生存を期待 しらる症例本存在した。

2. 再発巣が再発をさたした葴器内で限局性であれ ば，藏器欠損に対する再建方法を考慮した上で，積極 
的に切除にのぞさべきである。

3. 特に implantation によると考えられる胸腹壁再 発例では，視触診で早期に発見し，状況が許せば開腹 術す付加して十分に切除すべきである。

\section{文 献}

1) 斉藤洋一, 大柳治正, 藤原英利注か：胆道癌長期生 存例の全国集計. 胆と膵 $8: 11249-1314,1987$

2) 二村雄次, 塩野谷恵彦: 胆管癌治療のプロトコー ル. 臨外 42:876-882, 1987

3) 二村雄次, 近藤 哲, 河野 弘ほか：胆裹癌の進展 度と根治手術一se癌, si 癌一, 胆之膵 8 ： $1109-1116,1987$

4）日本胆道外科研究会編：胆道癌取扱い規約. 金原
出版, 東京, 1986

5）近藤 哲, 二村雄次, 早川直和ほ加：肝中央 2 区域 切除後, 腹壁再発をむ切除しえた胆衰粘液癌の 1 例. 日消外会誌 $20: 2225-2228,1987$

6）小高通夫, 竜 崇正, 碓井貞仁はか：消化器癌に対 する放射線療法 (肝・胆・膵)。明会誌 $85: 1067$ $-1071,1984$

7）上野桂一, 宮崎逸夫, 永川宅和：集学的治療が奏功 した肝門部胆管䅧再発の 1 例。胆と膵 $8: 1235$ $-1240,1987$

8）筒井光弘, 加藤 清, 赤井貞彦：興味ある進行胆擘 癌長期生存例。胆之膵 $8: 1245-1248,1987$ 